\title{
Phenotypic variability among pumpkin accessions in the Brazilian Semiarid
}

\author{
Rita Mércia E Borges ${ }^{1}$; Geraldo M de Resende ${ }^{1}$; Maria Auxiliadora C de Lima ${ }^{1}$; Rita de Cássia S Dias ${ }^{1}$; \\ Paloma Clementino da C Lubarino²; Regina Célia da S Oliveira ${ }^{3}$; Nadja Pollyanna da S Gonçalves ${ }^{4}$ \\ 'Embrapa Semiárido, C. Postal 23, 56300-970 Petrolina-PE; rmborges@cpatsa.embrapa.br; gmilanez@cpatsa.embrapa.br; maclima@ \\ cpatsa.embrapa.br; ritadias@cpatsa.embrapa.br; ${ }^{2} \mathrm{FACEPE} / \mathrm{CNPq}$; paloma.cruz@cpatsa.embrapa.br; ${ }^{3}$ Universidade de Pernambuco; \\ gina18464@hotmail.com; ${ }^{4} \mathrm{FACEPE} ;$ pollyanna.silva@cpatsa.embrapa.br
}

\begin{abstract}
The aim of this study was to estimate the phenotypic divergence among fourteen pumpkins accessions of the cucurbits Germplasm Active Bank of Embrapa Semiárido, in order to support breeding program to these species. Nine morphoagronomic descriptors were analyzed by the principal components and by UPGMA techniques. In the analysis of principal components, the formation of three contrasting clusters was observed, each one composed of two accessions. There occurred also the formation of one core group composed of five accessions, being the accessions called 683 and 684 collected in Bahia and the other in Maranhão. The most divergent accessions were 620,624 and 748. The variables of the greatest contribution to the genetic divergence were diameter, weight and average length of the fruit. In the UPGMA analysis, obtained from the symmetric matrices generated by the Mahalanobis distance for the nine descriptors, there was the formation of one core group, composed of ten accessions, whose similarity was $45.71 \%$, with geographically divergent accessions presenting the greatest similarity. Three accessions were not clustered with others. The study identified phenotypic variability for the analyzed characters and the absence of relationship between place of collection and phenotypic diversity.
\end{abstract}

Keywords: Cucurbita moschata, morphological descriptors, genetic resources, germplasm characterization, fruit descriptors.

\section{RESUMO}

Variabilidade fenotípica entre acessos de abóbora no Semiárido brasileiro

O objetivo deste trabalho foi estimar a divergência fenotípica em quatorze acessos de abóbora do Banco Ativo de Germoplasma de Cucurbitáceas da Embrapa Semiárido, com base em caracterização morfológica e agronômica para orientar trabalhos de melhoramento genético com a espécie. Nove descritores foram analisados utilizando-se técnicas de análise por componentes principais e análise de agrupamento (UPGMA). Na análise por componentes principais, observou-se a formação de três grupos contrastantes, cada um composto por dois acessos. Houve, ainda, a formação de um grupo principal composto por cinco acessos, sendo os acessos denominados 683 e 684 coletados na Bahia e os demais no Maranhão. Os acessos mais divergentes foram os 624 e 748. As variáveis de maior contribuição para a divergência genética foram diâmetro, peso e comprimento médio do fruto. Na análise por UPGMA, obtida a partir das matrizes simétricas geradas pela distância de Mahalanobis para os nove descritores, houve a formação de um grupo principal, composto por dez acessos, cuja similaridade foi de $45,71 \%$, com maior similaridade entre acessos geograficamente divergentes. Três acessos agruparam-se isoladamente em relação aos demais. O estudo identificou variabilidade fenotípica para os caracteres estudados e a ausência de relação entre local de coleta e diversidade fenotípica.

Palavras-chave: Cucurbita moschata, descritores morfológicos, recursos genéticos, caracterização de germoplasma, descritores de frutos.

(Recebido para publicação em 23 de fevereiro de 2010; aceito em 22 de agosto de 2011)

(Received on February 23, 2010; accepted on August 22, 2011)

$I^{n}$ pre-plant breeding studies, the steps of characterization and assessment allow identification of genetic variability in the accessions studied from germplasm banks or samples of natural populations and are extremely important. They serve to establish conservation strategies of one or more species, and in the germplasm bank organization, or identification of promising genotypes for future breeding actions. All the descriptors, whether quantitative or qualitative, contribute to determining this divergence to a greater or lesser degree (Moura, 2003a).

Among short cycle crops, pumpkin
(Cucurbita moschata L.) have great cropping potential, especially under the conditions of the Brazilian semiarid region and may be an important alternative for family agriculture. Normally most producers use seeds selected from previous harvests, from the chosen individuals that have the best sensory and production characteristics and then these selected seeds are mixed (Ramos et al., 1999, 2000).

Embrapa Semiárido, located in Petrolina, Pernambuco state, Brazil, has an Active Germplasm Bank (AGB) of Cucurbitaceas with 1.514 conserved accessions, 849 of the Cucurbita genus collected in different states of the Brazilian Northeast. Because of the need to obtain information on the accessions of the Cucurbita species that make up the AGB, especially on the variability existing among the accessions, promising accessions have been identified for future breeding programs especially to estimate divergent groups by multivariate analysis. These analyses have been carried out on various vegetables including the pumpkin (Bento et al., 2007; Buzar et al., 2007; Ramos, 2007), showing the importance of knowledge of the degree of variability in the species 
studied.

The objective of the present study was to estimate the phenotypic variability in 14 pumpkin accessions based on nine selected descriptors and on the clustering obtained from the dissimilarities among the pumpkin accessions belonging to the AGB at Embrapa Semiárido.

\section{MATERIAL AND METHODS}

The study was carried out on 14 Cucurbita moschata accessions belonging to the Active Germplasm Bank at Embrapa Semiárido collected in the Brazilian northeast (Table 1), chosen according to their variability for seed characteristics. The experiment was carried out at the Bebedouro Experimental Station, in the municipality of Petrolina (909'S; 40²2'W, 365.5 m average altitude) that has, according to the Köeppen classification, the Bswh-type climate, with a mean annual temperature of $26.4^{\circ} \mathrm{C}$, mean minimum $20.6^{\circ} \mathrm{C}$ and mean maximum $31.7^{\circ} \mathrm{C}$.

The phenotypic dissimilarity was estimated and obtained in a production cycle, from January to May 2008. A randomized block design was used with three replications and five plants per plot and the fruits were assessed quantitatively for nine pumpkin morphological descriptors, according to the Cultivar Protection Legislation (BRASIL, 2007). The sample consisted of 10 fruits per accession, collected randomly, in each block making a total of 30 fruits per accession. The following descriptors were used to analyze the fruits average weight $(\mathrm{kg})$, average fruit length $(\mathrm{cm})$, average fruit diameter $(\mathrm{cm})$, average skin thickness ( $\mathrm{mm})$, average pulp thickness in the upper, lower and side parts $(\mathrm{mm})$, average diameter of the internal cavity $(\mathrm{mm})$ and average penduncle length $(\mathrm{cm})$.

To obtain the estimates, the analysis of genetic divergence by principle components was used to compare the genotypes and the Mahalanobis distance, calculated from the data obtained, standardized based on the nine descriptors selected for accessions installed with repetition (Cruz \& Regazzi, 2001). The data obtained were analyzed using the computer resources of the Genes program, 2006 version (Cruz, 2006).

The symmetric matrices generated by the distances between the pairs of accession were used to form the cluster, using the Unweighted Pair Group Method with Arithmetic Mean (UPGMA) and the dissimilarities identified in dendrograms.

\section{RESULTS AND DISCUSSION}

In three dimensional dispersion graphs (Cruz \& Regazzi, 2001). Four contrasting groups were formed and three consisted of two accessions each: (I) accessions 627 and 618; (II) accessions 704 and 735 and (III) accessions 682 and 749. Group (IV), considered the largest group, consisted of the accessions 623,628, 629, 683 and 684 (Figure 1). Accessions 620, 624 and 748 were the most divergent in the dispersion graph forming isolated groups (Figure 1). The variables that may have contributed to the genetic divergence were average diameter, average weight and average length, with 46.24, 29.03 and $11.14 \%$ contribution to the variability among the accessions, respectively (Table 2 ).

Similar results were reported by Lubarino et al. (2008) for characterization of male flowers and leaves in the same accessions. The authors observed similarity in accession 63 and 628, belonging to group 4 (Figure 1) for male flower traits. In the same cluster, accessions 683 and 684 differed in origin from the others, both were collected in the state of Bahia (Table 1).

The analysis by UPGMA showed the formation of the biggest group, with accessions 623,684, 628, 683, $629,704,735,618$ and 627 , with $30 \%$ similarity and accession 682, with $45.71 \%$ similarity (Figure 2). These results were similar to those obtained by the dispersion graph (Figure 1). In

Table 1. Identification, common name and collection place of 14 pumpkin accessions (Cucurbita moschata L.) characterized as the nine descriptors of fruit proposed by MAPA (2007) (identificação, nome comum e local de coleta de 14 acessos de abóbora (Cucurbita moschata L.) caracterizados quanto a nove descritores de frutos propostos pelo MAPA (2007)). Petrolina, Embrapa Semiárido, 2008.

\begin{tabular}{ccll}
\hline $\begin{array}{c}\text { Access } \\
\mathbf{n}^{\mathbf{*}}\end{array}$ & $\begin{array}{c}\text { Code of the access } \\
\text { in the BAG }\end{array}$ & Common name & \multicolumn{1}{c}{ Local of the collection } \\
\hline 1 & 618 & abóbora & Colinas (MA) \\
2 & 620 & abóbora & Colinas (MA) \\
3 & 623 & abóbora & Colinas (MA) \\
4 & 624 & abóbora & Colinas (MA) \\
5 & 627 & abóbora & Colinas (MA) \\
6 & 628 & abóbora & Colinas (MA) \\
7 & 629 & abóbora & Colinas (MA) \\
8 & 682 & abóbora D'Ángola & Baixa Funda/Paripiranga (BA) \\
9 & 683 & abóbora D'Ángola & Baixa Funda/Paripiranga (BA) \\
10 & 684 & abóbora D’Ángola & Baixa Funda/Paripiranga (BA) \\
11 & 704 & abóbora & Turiaçu (MA) \\
12 & 735 & abóbora de leite & Distrito Boca do Caminho/Arari \\
& & & MA) \\
13 & 748 & abóbora de leite & Distrito Barro Branco/Barra do \\
& & & Corda (MA) \\
14 & 749 & abóbora de leite & Centro dos Ramos/Barra do \\
& & & Corda (MA) \\
\hline
\end{tabular}

*Numbering used for identification of pumpkin acessions in the graph of dispersion, on principal component analysis (numeração utilizada para identificação dos acessos no gráfico de dispersão, na análise de componentes principais). 


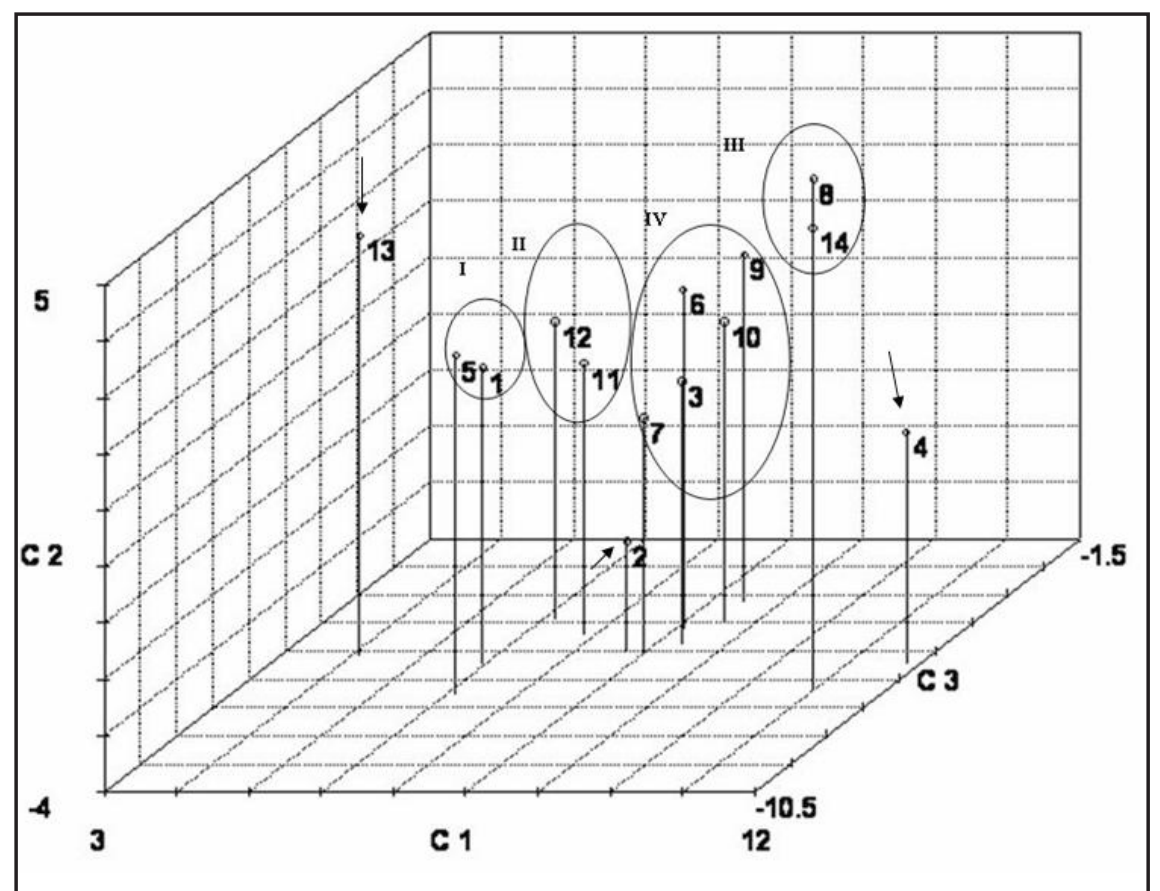

Figure 1. Dispersion diagram drawn from the component scores 1, 2 and 3 in the principal component analysis of pumpkin accessions. (I) acessions 627 and 618; (II) acessions 704 and 735; (III) acessions 682 and 749 and (IV) the larger group is composed of acessions $623,628,629,683$ and 684. Arrows show the most divergent accessions: 620, 624 and 748 (diagrama de dispersão elaborado a partir dos escores do componente 1, 2 e 3 da análise de componentes principais dos acessos de abóbora (C. moschata L.): (I) acessos 627 e 618; (II) acessos 704 e 735; (III) acessos 682 e 749 e (IV) maior grupo composto pelos acessos 623, 628, 629, 683 e 684. As setas mostram os acessos mais divergentes: 620, 624 e 748). Petrolina, Embrapa Semiárido, 2008.

the group formed, a greater degree of similarity observed between accessions with different origins. This was the case of accession 623, collected in Colinas (MA), with 5.7 similarity compared to
Table 2. Estimate of self values of pumpkin accessions (C. moschata L.) (estimativa dos autovalores de acessos de abóbora (Cucurbita moschata L.)). Petrolina, Embrapa Semiárido, 2008.

\begin{tabular}{cc}
\hline (\%) Individual & (\%) Accumulated \\
\hline 46.24 & 46.24 \\
29.03 & 75.27 \\
11.14 & 86.42 \\
8.20 & 94.61 \\
3.50 & 98.12 \\
0.88 & 99.00 \\
0.60 & 99.60 \\
0.26 & 99.86 \\
0.15 & 100.00 \\
\hline
\end{tabular}

was no association between collection location and phenotypic diversity. This absence of association was reported by Moura (2003b) in diversity studies applying ecogeographic descriptors. There are several factors that affect species variability distribution over their occurrence areas, including the form of reproduction, mating, migration, natural selection, genetic drift, genetic flow, (Hamrick, 1982). Therefore identifying the genotypic similarity in these geographically diverse accessions would require studies on molecular level.

Accessions 748, 749 and 624 clustered alone compared to the others

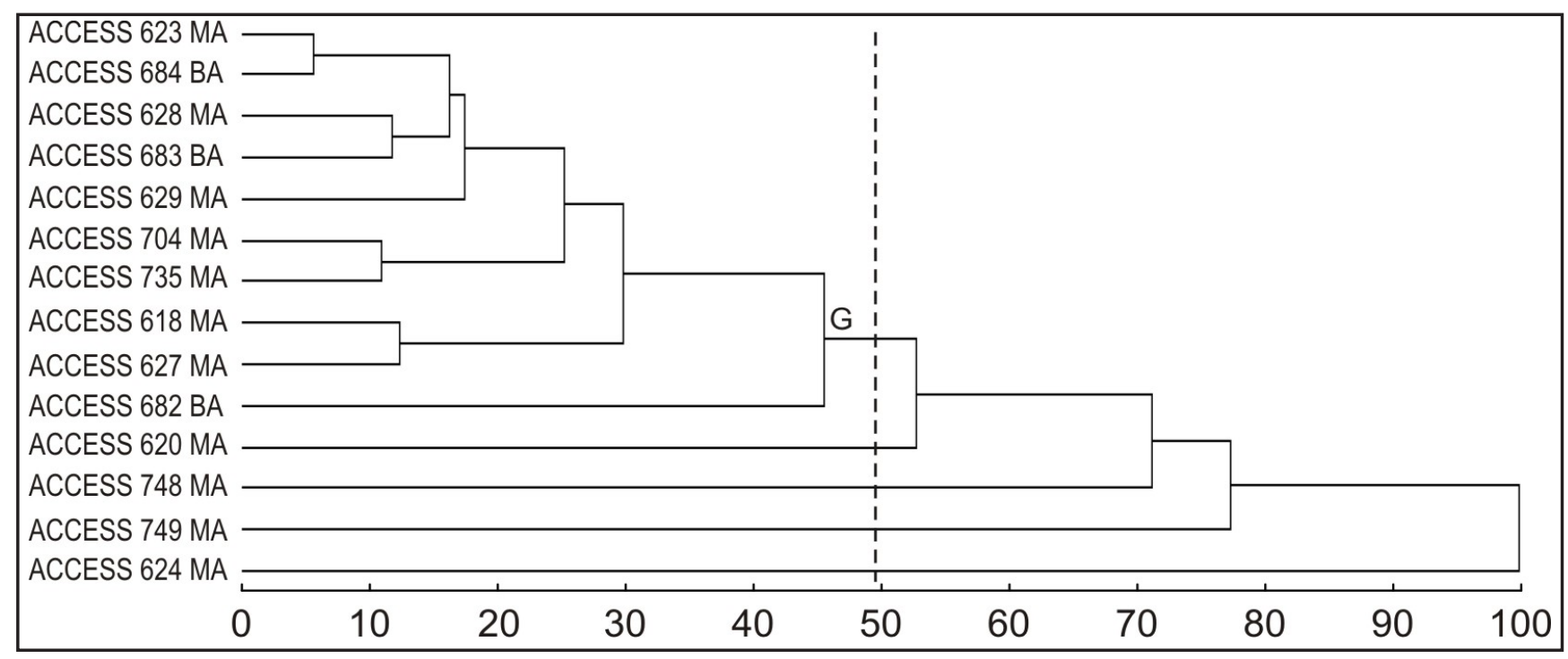

Figure 2. Dendrogram generated for the method UPGMA, from phenotype dissimilarity, in 14 pumpkin access: (G) larger group (dendrograma gerado pelo método UPGMA, a partir das dissimilaridades fenotípicas, em 14 acessos de abóbora (C. moschata L.): (G) Grupo maior). Petrolina, Embrapa Semiárido, 2008. 
with 71.4, 75.55 and $100 \%$ similarity, respectively. Accessions 748 and 624, were the most divergent both in the principle components analysis and UPGMA compared to the others.

The variability in pumpkin in the Brazilian North East was reported first by Ramos et al. (1999, 2000), where doing morpho-agronomic characterization of 40 accessions belonging to the pumpkin AGB at Embrapa Semiárido. The authors observed that the accessions had very variable characteristics and there was no accession that had all the desirable commercial traits among those studied.

The results obtained indicated great phenotypic variability for the traits studied, and accessions 748 and 624 were considered the most divergent. Costa et al. (2006) reported that identifying the different degrees of genetic diversity is important because it gives parameters to identify the promising parents. Moura (2003b) pointed out that identifying these accessions may serve to make future populations for the different strategies used in breeding programs.

To obtain hybrids, postulating rational and efficient criteria to identify parental types, the identification of divergent groups means savings in financial resources, time and labor. Furthermore, the principle components and UPGMA methods, used to identify divergent groups, presented similar results, especially for the formation of the largest group, and there was no association between collection location and phenotypic diversity.

\section{ACKNOWLEDGEMENTS}

The authors thank the CNPq and FACEPE, for the Scientific Initiation grants, (Paloma Lubarino) Technician Fixing (Nadja Pollyanna Gonçalves), respectively, and the staff at the Bebedouro Experimental Field for their dedicated and efficient work.

\section{REFERENCES}

BENTO CS; SUDRÉ CP; RODRIGUES R; RIVA EM. 2007. Descritores qualitativos e multicategóricos na estimativa da variabilidade fenotípica entre acessos de pimenta. Scientia Agraria 8: 147-154.

BRASIL. Ministério da Agricultura, Pecuária e Abastecimento. 2007. Disponível em http:// www.agricultura.gov.br. Acessado em 08 de outubro de 2007.

BUZAR AGR; OLIVEIRA VR; BOITEUX LS. 2007. Estimativa da diversidade genética de germoplasma de cebola via descritores morfológicos, agronômicos e bioquímicos. Horticultura Brasileira 25: 527-532.

COSTA MN; PEREIRA WE; BRUNO RLA; FREIRE EC; NÓBREGA MBM; MILANI M; OLIVEIRA AP. 2006. Divergência genética entre acessos e cultivares de mamoneira por meio de estatística multivariada. Pesquisa Agropecuária Brasileira 41: 1617- 622.

CRUZ CD. 2006. Análise e processamento de dados baseado em modelos biométricos e em Estatística Experimental: Programa GENES. Viçosa: UFV. (CD-ROM).

CRUZ CD; REGAZZI AJ. 2001. Modelos biométricos aplicados ao melhoramento genético. Viçosa: UFV. 390p.
HAMRICK JL. 1982. Plant population genetics and evolution. American Journal of Botany 69: 1685-1693.

LUBARINO PCC; BORGES RME; RESENDE GM; OLIVEIRA RCS; GONÇALVES NPS. 2008. Determinação do potencial germinativo e caracterização de acessos de Cucurbita moschata e C. maxima no Vale do São Francisco. In: CONGRESSO DE PESQUISAE INOVAÇÃO DA REDE NORTE NORDESTE DE EDUCAÇÃO TECNOLÓGICA, 3. Anais eletrônicos... Fortaleza: CEFET-CE. (CDROM). Disponível em http://www.cpatsa. embrapa.br/public_eletronica/ downloads/ OPB1932.pdf. Acessado em 02 de novembro de 2008.

MOURA MCCL. 2003. Identificação de fontes de resistência ao Potívirus ZYMV e diversidade genética e ecogeográfica em acessos de abóbora. Viçosa: UFV. 98p (Tese mestrado).

MOURA EF. 2003. Divergência genética entre acessos de jaborandi (Pilocarpus microphyllus). Lavras: UFLA. 75. (Tese mestrado).

RAMOS SRR. 2007. Genetic diversity based on AFLP molecular markers and indicators for the establishment of a core collection for pumpkim (Cucurbita moschata) for north-east Brazil. Plant Genetic Resources Newsletter 149: 43.

RAMOS SRR; QUEIROZ MA; CASALI VWD; CRUZ CD. 2000. Divergência genética em germoplasma de abóbora procedente de diferentes áreas do Nordeste. Horticultura Brasileira 18: 195-199.

RAMOS SRR; QUEIROZ MA; CASALI VWD; CRUZ CD.1999. Recursos genéticos de Cucurbita moschata: caracterização morfológica de populações locais coletadas no Nordeste brasileiro. In: QUEIROZ MA; GOEDERT CO; RAMOS SRR. (eds). Recursos genéticos e melhoramento de plantas para o Nordeste brasileiro. Petrolina: Embrapa Semi-Árido; Brasília: Embrapa Recursos Genéticos e Biotecnologia. Disponível em http://www.cpatsa.embrapa. br/catalogo/ livrorg/index.html. Acessado em 08 de outubro de 2007. 